\title{
TINJAUAN HUKUM TERHADAP NOMINEE AGREEMENT KEPEMILIKAN SAHAM PADA PENANAMAN MODAL ASING BERBENTUK PERUSAHAAN JOINT VENTURE
}

\author{
(Legal Review of Nominee Shareholders Agreement of Foreign Direct Investment In \\ The Form of Joint Venture Company)
}

\author{
Muh. Afdal Yanuar \\ Pusat Pelaporan \& Analisis Transaksi Keuangan \\ Jl. Ir. H. Djuanda Nomor 35, Kb. Kelapa, Gambir, Jakarta Pusat, 10120 \\ e-mail: yanuarafdal10@gmail.com
}

\begin{abstract}
Abstrak
Melalui tulisan ini, akan dijelaskan konsep dan pengaturan nominee agreement kepemilikan saham dalam kegiatan investasi, serta reformulasi terhadap nominee shareholders dalam kegiatan Penanaman Modal Asing melalui Perusahaan Joint Venture di Indonesia. Penelitian ini merupakan penelitian normatif dengan pendekatan konseptual dan pendekatan peraturan perundang-undangan dengan menggunakan data sekunder. Dalam penelitian ini, dipahami bahwa keberadaan Peraturan Presiden Nomor 10 Tahun 2021 membatasi investor asing pada bidang-bidang usaha tertentu untuk menanamkan modalnya di Indonesia. Hal tersebut memungkinkan bagi investor asing untuk melakukan pengelabuan terhadap hukum yang berlaku, ketika pendirian perusahaan joint venture di Indonesia, di antaranya dengan menunjuk nominee shareholders pada perusahaan joint venture tersebut. Hubungan hukum antara beneficiary (entitas asing) dengan nominee shareholders tersebut didasarkan pada nominee agreement. Melalui nominee agreement, nominee shareholders bertindak untuk dan atas nama beneficiary (entitas asing). Hal tersebut, status quo, dilarang dalam UU Penanaman Modal dan UU Perseroan Terbatas di Indonesia. Akan tetapi, dengan melihat keberadaan Peraturan Presiden tentang Pemilik Manfaat, terdapat kewajiban bagi korporasi untuk menentukan pemilik manfaatnya (termasuk Pemilik manfaat sebenarnya). Sehingga, seharusnya terhadap nominee shareholders (yang dilakukan berdasarkan nominee agreement) tidaklah dilarang sebagaimana status quo, melainkan dibatasi oleh hukum, perihal mana yang boleh dan mana yang tidak boleh dilakukannya.
\end{abstract}

Kata kunci: beneficiary, nominee, dan joint venture.

\begin{abstract}
This paper explain about the concept and arrangement of nominee shareholders agreement in investment activities, and the reformulation of nominee shareholders regulations in foreign direct investment activities through a Joint Venture Company in Indonesia. This research is a normative study with a conceptual and a statutory approach, using secondary data. In this study, it is understood that the existence of Presidential Decree 10/2021 restricts foreign investors in certain business fields to invest in Indonesia. This makes possibility for foreign investors to cheat the applicable law when the joint venture company was established in Indonesia, among others by appointing nominee shareholders in the joint venture company. The legal relationship between beneficiary (foreign entity) and nominee shareholders is based on a nominee agreement. Through a nominee agreement, nominee shareholders act, for and on behalf of, the beneficiary (foreign entity). This, in status quo, is prohibited in Investment Law and Limited Company Law. However, by looking at the existence of the Presidential Decree on Beneficial Ownership, there is an obligation for corporation to determine its beneficial owner (including the ultimate beneficial ownership). So, necessarily, nominee shareholders (under a nominee agreement) not prohibited as in status quo, but limited by law, regarding which one can be done and cannot be done.
\end{abstract}

Keywords : beneficiary, nominee, and joint venture. 


\section{A. Pendahuluan}

Perkembangan perekonomian suatu negara, terlebih lagi negara berkembang, sangat ditentukan oleh pertumbuhan penanaman modal asing. Arus penanaman modal asing sendiri bersifat fluktuatif, tergantung dari iklim investasi negara yang bersagkutan. Bagi negara penanam modal, sebelum melakukan investasi terlebih dahulu akan melakukan penilaian terhadap aspek-aspek yang turut mempengaruhi iklim investasi, yaitu: kesempatan ekonomi (economic opportunity); kepastian hukum (legal certainty); dan stabilitas politik (political stability). ${ }^{1} \mathrm{Hal}$-hal tersebutlah yang dibutuhkan oleh negara-negara berkembang untuk mendatangkan investor.

Sebagai sebuah negara yang berdaulat, negara memiliki hak yang diakui oleh hukum internasional diantaranya: hak kesederajatan (equality), yurisdiksi wilayah (territorial jurisdiction), hak untuk menentukan nasionalitas bagi penduduk di wilayahnya, dan hak untuk mengijinkan dan menolak atau melarang orang untuk masuk dan keluar dari wilayahnya. ${ }^{2}$ Berdasarkan uraian tersebut, salah satu yang menjadi hak bagi negara di wilayah kedaulatannya ialah terkait hak untuk mengijinkan dan menolak atau melarang orang untuk masuk dan keluar dari wilayahnya. Yang mana hal tersebut juga dapat dikaitkan dengan permasalahan investasi asing. Investasi asing sendiri merupakan kegiatan menanam modal untuk melakukan usaha di wilayah negara Republik Indonesia yang dilakukan oleh penanam modal asing, yang dilakukan atas dasar perjanjian (kontrak).

Investasi merupakan kegiatan menanamkan uang atau modal yang dilakukan dengan motif untuk meningkatkan atau setidak-tidaknya mempertahankan nilai modalnya. ${ }^{3}$ Indonesia sebagai sebuah negara yang kaya akan sumber daya alamnya tentu menjadi sorotan investorinvestor asing untuk dapat berinvestasi terhadap pengelolaan sumber daya alam tersebut. Apalagi di satu sisi, melalui kegiatan investasi asing, perekonomian Indonesia juga dapat mengalami perkembangan.

Dalam pengelolaan sumber daya alam di wilayah Indonesia sendiri, di dalam UUD Negara RI Tahun 1945, yang merupakan grand design Penyelenggaraan kehidupan bernegara, telah menegaskan bahwa "cabang-cabang produksi yang menguasai hajat hidup orang bank dikuasai oleh negara", ${ }^{4}$ dan "bumi, air dan kekayaan alam yang terkandung di dalamnya dikuasai oleh negara dan dipergunakan untuk sebesarbesarnya kemakmuran rakyat". ${ }^{5}$ Artinya, terdapat 'hak menguasai negara' terhadap pengelolaan kekayaan negara dan cabang-cabang produksi dalam rangka pembangunan perekonomian nasional. Berdasarkan Putusan MK No 36/ PUU-X/2012 dikatakan bahwa wilayah "hak menguasai negara" adalah melingkupi mandat konstitusi kepada negara untuk mengadakan kebijakan (beleid) dan tindakan pengurusan (bestuursdaad), pengaturan (regelendaad),

1 Pancras J. Nagy, Country Risk: How to Asses, Quantify, and Monitor, (London: Euronomy Publications), 1979, hlm. 54.

2 R.C. Hingorani, Modern International Law: Second Edition, (New Delhi: Oxford \& IBH Publishing Co), 1982, hlm.117118

3 Ida Bagus Rachmadi Supancana, Kerangka Hukum dan Kebijakan Investasi Langsung di Indonesia, (Jakarta: Ghalia Indonesia), 2006, hlm. 1.

4 Lihat Pasal 33 ayat (2) UUD Negara RI Tahun 1945.

5 Lihat Pasal 33 ayat (3) UUD Negara RI Tahun 1945. 
pengelolaan (beheersdaad), dan pengawasan (toezichthoudensdaad) untuk tujuan sebesarbesarnya kemakmuran rakyat. ${ }^{6}$

Fungsi pengurusan (bestuursdaad) oleh negara dilakukan oleh Pemerintah dengan kewenangannya untuk mengeluarkan dan mencabut fasilitas perizinan (vergunning), lisensi (licentie), dan konsesi (consessie). Fungsi pengaturan oleh negara (regelendaad) dilakukan melalui kewenangan legislasi oleh DPR bersama Pemerintah, dan regulasioleh Pemerintah. Fungsi pengelolaan (beheersdaad) dilakukan melalui mekanisme pemilikan saham (share-holding) dan/atau sebagai instrumen kelembagaan, yang melaluinya negara, c.q. Pemerintah, mendayagunakan penguasaannya atas sumber-sumber kekayaan itu untuk digunakan bagi sebesar-besarnya kemakmuran rakyat. Demikian pula fungsi pengawasan oleh negara (toezichthoudensdaad) dilakukan oleh Negara, c.q. Pemerintah, dalam rangka mengawasi dan mengendalikan agar pelaksanaan penguasaan oleh negara atas sumber-sumber kekayaan dimaksud benar-benar dilakukan untuk sebesarbesarnya kemakmuran seluruh rakyat. ${ }^{7}$

Dalam konteks Penanaman Modal Asing sendiri, eksistensi negara untuk mengontrol jalannya kegiatan investasi oleh investor asing tetap perlu dibatasi dengan hak-hak menguasai negara tersebut, yang di antaranya adalah hak negara untuk melakukan pengaturan terhadap peluang dan pembatasan bagi investor asing dalam mengelola segala sumber daya alam yang ada di Indonesia, melalui peraturan- peraturan hukum positif yang berlaku di wilayah Negara Indonesia dalam rangka pelaksanaan Penanaman Modal Asing, yang dalam konteks ini dimuat dalam UU No 25 Tahun 2007 tentang Penanaman Modal, dan peraturan turunannya.

Dalam Pasal 6 Ayat (1) UU Penanaman Modal diberikan amanah kepada pemerintah untuk memberikan perlakuan yang sama kepada semua penanam modal, baik penanam modal dalam negeri maupun penanam modal asing yang melakukan penanaman modal di Indonesia, sesuai dengan ketentuan peraturan perundang-undangan. Ketentuan tersebut merupakan kongkretisasi prinsip the most favoured nations principles yang dianut oleh GATS/WTO. ${ }^{8}$ Berdasarkan prinsip tersebut, maka di Indonesia, terdapat kesempatan dan peluang investasi yang sama antara investor asing maupun lokal, meskipun tetap terdapat batasan-batasan tertentu bagi investor asing untuk berinvestasi, di antaranya melalui adanya ketentuan perihal bidang usaha yang tidak boleh dilaksanakan investasi (baik investasi lokal maupun investasi asing), maupun kegiatan usaha yang membatasi maksimum kepemilikan saham, ataupun memberi syarat-syarat tertentu, bagi investor asing. Hal-hal tersebut lebih lanjut diatur dalam Perpres No 10 Tahun 2021 tentang Bidang Usaha Penanaman Modal.

Berdasarkan peraturan tersebut, bagi investor, setidaknya bidang usaha berdasarkan Perpres tersebut, dapat dibedakan atas Bidang Usaha Tertutup atau hanya dilakukan oleh Pemerintah Pusat, ${ }^{9}$ dan Bidang Usaha terbuka ${ }^{10}$.

6 Lihat Ratio Decidendi [3.11] Putusan MK No 36/PUU-X/2012, hlm. 99.

7 Lihat Ratio Decidendi [3.11] Putusan MK No 36/PUU-X/2012, hlm. 99 - 100.

8 Erman Rajagukguk dan Rosa Agustina, Hukum Investasi dan Pasar Modal, (Jakarta: Pascasarjana FHUI), 2010, hlm. 57.

9 Bidang usaha yang tidak dapat diusahakan melalui penanaman modal (vide Pasal 12 ayat (2) UU No 25 Tahun 2007 tentang Penanaman Modal jo UU No 11 Tahun 2020 tentang Cipta Kerja). Jenis bidang usaha ini sering jua disebut sebagai Daftar Negatif Investasi (DNI).

10 Bidang usaha yang dapat diusahakan melalui penanaman modal (vide Lihat Pasal 2 Perpres Nomor 10 Tahun 2021 
Khusus Bidang usaha terbuka sendiri, meliputi: Bidang Usaha Prioritas, ${ }^{11}$ Bidang Usaha yang dialokasikan atau kemitraan dengan Koperasi dan UMKM, ${ }^{12}$ Bidang Usaha dengan Persyaratan tertentu, ${ }^{13}$ dan Bidang Usaha terbuka lainnya ${ }^{14}$.

Dari bidang-bidang usaha di atas, khususnya bidang usaha yang terbuka untuk investasi, jika dilihat dari perspektif investor asing, maka dapat dipahami bahwa terdapat: bidang usaha yang terbuka untuk investasi tetapi sama sekali tidak diberi ruang bagi investor asing untuk diusahakan; bidang usaha yang terbuka untuk investasi tetapi terdapat batasan kepemilikan saham bagi investor asing; dan bidang usaha yang terbuka untuk investasi, dan tidak memberikan batasan kepemilikan saham dari investor asing.

Merujuk pada bidang-bidang usaha di atas, investor asing yang semula melihat potensi yang besar dalam pengelolaan sumber daya alam di Indonesia sebagai ladang yang besar untuk meraup keuntungan, pada akhirnya akan melihatnya sebagai sebuah tantangan tersendiri. Apabila kemudian terdapat pemikiran yang pragmatis terhadap tujuannya untuk meraup benefit yang besar tersebut, tidak menutup kemungkinan akan adanya investor-investor asing yang menggunakan pemikiran the ends justify the means (menghalalkan segala cara untuk mencapai tujuan) untuk memperoleh benefit dalam pengelolaan sumber daya alam atau cabang-cabang produksi lain di Indonesia dengan mudah, dengan mengelabui hukum yang berlaku.

Misalnya, terhadap bidang usaha: (a) yang terbuka untuk investasi tetapi sama sekali tidak diberi ruang bagi investor asing untuk diusahakan; atau (b) yang terbuka untuk investasi tetapi terdapat batasan kepemilikan saham bagi investor asing, tidak menutup kemungkinan bagi investor asing tersebut menggunakan entitas (orang/badan usaha) Indonesia, sebagai orang suruhannya, untuk menjadi pihak atas nama (nominee) ${ }^{15}$ dari investor asing tersebut, yang nantinya menjadi nominee shareholders dalam pembentukan Perusahaan joint venture berbentuk Perseroan Terbatas $^{16}$ dalam mengelola bidang usaha yang

tentang Bidang Usaha Penanaman Modal).

11 Bidang usaha ini terbuka baik bagi investor dalam negeri maupun investor asing, selama memenuhi kriteria bidang usaha, cakupan produk, dan persyaratan yang telah ditentukan (vide Pasal 4 Perpres Nomor 10 Tahun 2021 tentang Bidang Usaha Penanaman Modal).

12 Dalam bidang Usaha ini, ada yang memang khusus dialokasikan untuk Koperasi dan UMKM (terbuka bagi investor lokal berbentuk Koperasi dan UMKM, dan tertutup bagi investor asing); dan ada juga yang terbuka untuk Usaha Besar yang bermitra dengan Koperasi dan UMKM (terbuka bagi investor dalam negeri maupun investor asing melalui kemitraan, diantaranya joint venture, dengan Koperasi dan UMKM) (vide Pasal 5 Perpres Nomor 10 Tahun 2021 tentang Bidang Usaha Penanaman Modal).

13 Dalam bidang usaha ini, terbuka bagi investor dalam negeri maupun investor asing, selama memenuhi persyaratan penanaman modal, baik bagi investor dalam negeri, investor asing, maupun dengan perizinan khusus. Dalam bidang usaha ini, bagi investor dalam negeri maupun investor asing, terdapat batasan kepimilikan saham maksimum dalam penanaman modal (vide Pasal 6 Perpres Nomor 10 Tahun 2021 tentang Bidang Usaha Penanaman Modal).

14 Bidang usaha ini dapat diusahakan oleh semua penanam modal. Artinya, baik investor dalam negeri maupun asing, dapat menguasai saham dalam kegiatan usaha ini hingga 100\% sekalipun (vide Pasal 3 ayat (2) Perpres Nomor 10 Tahun 2021 tentang Bidang Usaha Penanaman Modal).

15 Nominee adalah seseorang yang telah ditunjuk atau diajukan untuk suatu urusan yang dimaksudkan untuk bertindak menggantikan seorang lainnya.

David Kirupan, Aspek Hukum Penanaman Modal Asing Di Indonesia, (Jakarta: Penerbit Kencana Prenada Media Group), 2013, hlm. 43.

16 Berdasarkan Pasal 5 ayat (2) UU Nomor 25 Tahun 2007 tentang Penanaman Modal dinyatakan bahwa Penanaman 
membatasi maksimum kepemilikan saham bagi investor asing tersebut. Penanaman modal asing sendiri biasanya dilakukan dengan mendirikan perusahaan patungan (joint venture company), dengan cara mengonversikan pinjaman menjadi penyertaan mayoritas pada suatu perusahaan dalam negeri (berbentuk Perseroan Terbatas), dan lain-lain. ${ }^{17}$ Contoh ilustrasi kasus yang menggunakan nominee agreement dalam suatu kegiatan investasi asing dapat diuraikan sebagai berikut:

A adalah investor Asing yang menanamkan modal di sektor 'Angkutan Laut dalam negeri untuk wisata'. Berdasarkan Perpres 10 Tahun 2021, sektor tersebut merupakan bidang usaha terbuka dengan syarat tertentu. Adapun syarat yang ditentukan berdasarkan lampiran Perpres tersebut adalah modal asing maksimal 49\%. ${ }^{18}$ Akan tetapi, sebelum hendak membentuk perusahaan joint venture berbentuk Perseroan Terbatas, A yang melalui orang perpanjangan tangannnya yang merupakan WNI, yang memiliki CV yang bergerak di bidang angkutan laut juga, bernama B, untuk menjadikan CV nya sebagai atas nama (nominee) dari $A$, dengan membentuk sebuah nominee agreement antara A dengan CV milik B. Dalam nominee agreement tersebut memerintahkan agar CV milik B menjadi pihak atas nama (nominee) dari A untuk pembentukan sebuah perusahaan joint venture untuk mengelola bidang usaha 'angkutan Laut dalam negeri untuk wisata' di Indonesia. Modal pun diberikan oleh $\mathrm{A}$ kepada B. Hingga akhirnya, dalam pendirian perusahaan joint venture tersebut, $\mathrm{A}$ mengambil bagian saham sebesar $49 \%$, sedangkan CV milik B mengambil bagian saham sebesar $31 \%$ (yang modalnya seluruhnya milik $A$ ), dan $20 \%$ sisanya milik perusahaan dalam negeri lainnya. Adapun ketika Perusahaan tersebut memperoleh untung, keuntungan yang diperoleh A melebihi 49\% karena sebagian diperoleh melalui pembagian dari B kepada A, karena $B$ sesungguhnya bertindak sebagai nominee dari A melalui nominee agreement.

Nominee Agreement sendiri bukanlah merupakan praktik yang baru di Indonesia. Justru terkadang nominee agreement sering digunakan oleh pelaku usaha, termasuk investor asing untuk menyelundupi hukum yang berlaku. ${ }^{19}$ Dalam konteks investasi asing, diantaranya adalah untuk mengelabui ketentuan perihal pembatasan kepemilikan saham investor asing dalam suatu bidang usaha. Padahal sebenarnya penggunaan nominee dalam kegiatan penanaman modal (baik lokal maupun asing) sendiri di larang dalam UU Penanaman Modal, sebagaimana pada ketentuan Pasal 33

modal asing wajib dalam bentuk perseroan terbatas berdasarkan hukum Indonesia dan berkedudukan di dalam wilayah negara Republik Indonesia, kecuali ditentukan lain oleh undang-undang.

17 Ana Rokhmatussa'dyah dan Suratman, Hukum Investasi dan pasar Modal, (Jakarta: Sinar Grafika), 2009, hlm. 5.

18 Lihat Lampiran III poin 11 Perpres Nomor 10 Tahun 2021 tentang Bidang Usaha Penanaman Modal

19 Munir Fuady mengatakan bahwa tidak ada suatu perjanjian lain yang eksistensinya dalam sistem hukum di Indonesia paling kontrovesional selain dari nominee agreement. Hal ini disebabkan antara lain oleh faktor-faktor sebagai berikut: (a) Nominee itu sendiri tidak berasal dari sistem hukum Indonesia; dan (b) Seringkali nominee ini dipakai untuk menyeludupi hukum tertentu.

Munir Fuady, Hukum Bisnis Dalam Teori dan Praktek, Buku 3, (Bandung: Penerbit PT. Citra Aditya Bakti), 2002, hlm. 105. 
UU Penanaman Modal yang menyatakan bahwa "Penanam modal dalam negeri dan penanam modal asing yang melakukan penanaman modal dalam bentuk perseoran terbatas dilarang membuat perjanjian dan/atau pernyataan yang menegaskan bahwa kepemilikan saham dalam perseroan terbatas untuk dan atas nama orang lain". Akan tetapi, terhadap praktik nominee shareholders melalui nominee agreement, pemerintah seakan tutup mata dan membiarkan praktik nominee tersebut semakin berkembang. Pemerintah beranggapan investasi yang ditanamkan meskipun dengan menggunakan nominee tetap memberikan keuntungan, yakni dengan adanya penambahan tenaga kerja dan lain sebagainya. Sementara Undang-undang jelas melarang praktik tersebut. Kurangnya pengawasan serta ringannya sanksi membuat praktik kepemilikan saham berbentuk nominee semakin marak terjadi di Indonesia sehingga semakin merugikan rakyat Indonesia. Secara tidak langsung hal demikian dapat dikatakan sebagai penjajahan masa kini. ${ }^{20}$ Berdasarkan hal-hal yang telah diuraikan dalam diatas, maka Penulis mengangkat sebuah judul dalam tulisan ini yaitu "Tinjauan Hukum Terhadap Nominee Agreement Kepemilikan Saham Pada Penanaman Modal Asing Berbentuk Perushaan Joint Venture". Adapun berdasarkan hal-hal yang diuraikan dalam latar belakang diatas, maka penulis mengidentifikasi masalah-masalah yang perlu diuraikan melalui tulisan ini, yaitu (1)
Bagaimana konsep dan pengaturan nominee agreement kepemilikan saham dalam kegiatan investasi di Indonesia?; dan (2) Bagaimana reformulasi pengaturan nominee shareholders dalam kegiatan Penanaman Modal Asing melalui Perusahaan Joint Venture di Indonesia?

\section{B. Metode Penelitian}

Penelitianinimerupakan penelitian normatif dengan pendekatan konseptual (conseptual approach) dan pendekatan peraturan perundang-undangan (statute approach). Artinya, penelitian ini mengacu pada telaahan konseptual dan peraturan perundang-undangan yang berlaku terhadap isu yang dibahas, dengan didasarkan pada data sekunder sebagai data kepustakaan dengan menggunakan metode berpikir deduktif, ${ }^{21}$ dengan bentuk kebenaran yang hendak dicapaiadalah kebenaran koheren. ${ }^{22}$ Hal tersebut dapat digambarkan melalui pengujian teori-teori yang memproyeksikan posibilitas nominee shareholders agreement dalam suatu Perusahaan (Perseroan Terbatas), termasuk pula dalam kegiatan investasi asing oleh perusahaan tersebut. Kemudian diuji dalam konteks Indonesia, dan ditemukan sebuah gambaran utuh bahwa hal tersebut pun juga dimungkinkan terjadi di perusahaanperusahaan Indonesia. Selanjutnya, Penelitian ini bersifat preskriptif, yakni dengan terlebih dahulu mengidentifikasi ruang lingkup nominee agreement kepemilikan saham yang dimuat

20 lin Indriyani, "Perkembangan Hukum: Perseroan Terbatas Dan Praktik Penggunaan Nominee Oleh Investor Asing", Prosiding Seminar IImiah Nasional Fakultas Hukum Universitas Pamulang, Juli 2017 hlm. 263.

21 Cara berpikir deduktif adalah cara berpikir yang penarikan kesimpulannya ditarik dari sesuatu yang sifatnya umum yang sudah dibuktikan bahwa dia benar, dan kesimpulan itu ditujukan untuk sesuatu yang sifatnya khusus. Sedarmayanti \& Syarifudin Hidayat. Metodologi Penelitian, (Bandung: Mandar Maju), 2002, hlm. 23.

22 Kebenaran koheren yaitu suatu pengetahuan, teori, pernyataan, proposisi, atau hipotesis dianggap benar kalau sejalan dengan pengetahuan, teori, pernyataan, proposisi, atau hipotesis lainnya, yaitu kalau proposisi itu meneguhkan dan konsisten dengan proposisi sebelumnya yang dianggap benar.

A. Sonny Keraf \& Mikhael Dua, Ilmu Pengetahuan, Sebuah Tinjauan Filosofis, (Yogyakarta: Kanisius), 2001, hlm. 68. 
dalam peraturan perundang-undangan status quo, untuk selanjutnya dilakukan analisis terhadap isu hukum yang muncul seputar nominee agreement kepemilikan saham tersebut, melalui penelaahan ketentuan normatif yang didasarkan pada doktrin, teori dan konsep hukum terkait, serta memberikan insight berupa konsep-konsep yang perlu diadopsi dalam rangka mengatasi masalah tersebut.

\section{Pembahasan}

\section{Konsep dan Pengaturan Nominee Agreement Kepemilikan Saham dalam Kegiatan Investasi di Indonesia}

Berdasarkan Pasal 5 ayat (2) UU Penanaman Modal, ditentukan bahwa Investor asing yang hendak berinvestasi di Indonesia, maka bagi mereka wajib mendirikan badan usaha di Indonesia berbentuk Perseroan Terbatas. Dalam pendirian Perseroan Terbatas sendiri, terdapat prinsip bahwa harus didirikan melalui sebuah akta notaris. Adanya Prinsip dasar tersebut, yang mensyaratkan pendirian Perseroan Terbatas melalui sebuah perjanjian (akta notaris), sebagaimana dalam Pasal 7 ayat (1) UU Nomor 40 Tahun 2007 tentang Perseoran Terbatas jo UU Nomor 11 Tahun 2020 tentang Cipta Kerja, menyebabkan pendirian Perseroan Terbatas harus dilakukan oleh 2 orang atau lebih sebagai pemegang saham, karena tidak mungkin satu orang mengadakan perjanjian dengan dirinya sendiri. Syarat pendirian perseroan terbatas dengan 2 (dua) orang atau lebih ini juga memicu timbulnya nominee shareholder, yang pada umumnya pemodal asing ingin menguasai perseroan terbatas secara tidak terbatas. ${ }^{23}$

\section{Nominee Shareholder merupakan}

Pemegang saham yang namanya tercatat sebagai pemilik sah berdasarkan hukum atas saham, yang dibuktikan dengan terdaftar sebagai pemegang saham dalam Daftar Pemegang Saham dari perusahaan yang bersangkutan. Meskipun nominee shareholder terdaftar sebagai pemilik sah saham perusahaan, nominee shareholder dalam melakukan tindakannya, didasarkan pada petunjuk dari seseorang yang sebenarnya memiliki saham tersebut (beneficiary). ${ }^{24}$ Adapun hubungan hukum antara beneficial owner dengan nominee tersebut timbul melalui sebuah perjanjian (agreement). Terdapatnya dua pihak dalam nominee agreement tersebut melahirkan dua jenis kepemilikan, yaitu pemilik yang tercatat dan diakui secara hukum (legal owner/juridische eigendom) dan pemilik yang sebenarnya (beneficiary/economische eigendom) yang menikmati keuntungan berikut kerugian yang timbul dari benda yang dimiliki oleh nominee. ${ }^{25}$ Artinya, Nominee agreement merupakan sebuah perjanjian yang dilakukan antara beneficiary dengan nominee yang memberikan ruang kepada nominee untuk bertindak untuk dan atas nama beneficiary serta sesuai dengan petunjuk dan arahan dari beneficiary.

Berdasarkan hukum, legal owner adalah

23 Lucky Suryo Wicaksono, "Kepastian Hukum Nominee Agreement Kepemilikan Saham Perseroan terbatas", Jurnal Hukum lus Qua lustum, Vol.23 No.1, Januari 2016, hlm. 44.

24 Nominee Shareholders is a company member who holds the shares registered in his name for the benefit of another. The identity of the person with the true interest may be subject to disclosure and to investigation under the Companies Act."

Syahrijal Syakur, Urgensi Pengaturan Nominee Agreement Dalam Rangka Pencegahan Tindak Pidana Pencucian Uang, (Jakarta: PPATK), 2020, hlm. 26.

25 Lucky Suryo Wicaksono, Op.Cit., hlm. 48. 
pemegang hak yang sah atas benda tersebut, yang tentunya memiliki hak untuk mengalihkan, menjual, membebani, menjaminkan serta melakukan tindakan apapun atas benda yang bersangkutan, sedangkan pihak beneficiary tidak diakuisebagai pemilikatas benda secarahukum. ${ }^{26}$ Bentuk struktur nominee pemegang saham (nominee shareholders) dalam prakteknya di Indonesia dapat dikategorikan menjadi 2 (dua) jenis yaitu Struktur nominee langsung (direct nominee structure), dan Struktur nominee tidak langsung (indirect nominee structure).

a. Struktur Nominee Langsung (Direct Nominee Structure)

Struktur nominee langsung (direct nominee structure) adalah suatu struktur nominee yang dibentuk dengan secara langsung membuat perjanjian dan/atau pernyataan yang menegaskan bahwa kepemilikan saham dalam suatu perseroan terbatas adalah untuk dan atas nama orang lain. Struktur ini pada umumnya dibentuk dengan membuat perjanjian nominee (nominee agreement) atau pernyataan nominee (nominee statement). ${ }^{27}$

Perjanjian Nominee dikategorikan sebagai salah satu bentuk dari Perjanjian Innominaat karena belum ada pengaturan secara khusus tentangnya dan tidak secara tegas disebutkan dalam pasal-pasal KUHPerdata, namun dalam praktiknya sering dijumpai di Indonesia. Dalam praktiknya tidak jarang juga ditemukan suatu struktur nominee pemegang saham yang dibentuk dengan menggunakan Pernyataan nominee (nominee statement). Pada dasarnya materi dari suatu pernyataan nominee adalah pernyataan dari pemegang saham nominee yang menerangkan bahwa uang yang disetor pada perseroan adalah berasal dari beneficiary sehingga segala keuntungan dan kerugian termasuk beban pajak yang timbul sehubungan dengan kepemilikan saham oleh pemegang saham nominee pada perseroan merupakan hak dan tanggung jawab dari beneficiary. ${ }^{28}$

Bersamaan dengan pembuatan nominee agreement atau nominee statement, pada umumnya pembentukan struktur nominee pemegang saham turut dilengkapi dengan kuasa mutlak yang diberikan oleh nominee kepada beneficiary untuk melakukan segala tindakan yang berhubungan dengan saham-saham yang dipegang oleh nominee dalam perseroan termasuk untuk menghadiri Rapat Umum Pemegang Saham yang diadakan oleh Perseroan, menerima dividen, dan/atau mengalihkan hak atas saham. ${ }^{29}$

b. Struktur nominee tidak langsung (indirect nominee structure)

Struktur nominee tidak langsung (indirect nominee structure) adalah suatu struktur nominee yang dibentuk dengan cara membuat beberapa perjanjian yang berlapis-lapis dengan tujuan agar beneficiary secara tidak langsung dapat mengendalikan serta menerima manfaat

26 Syahrijal Syakkur, Op.Cit., hlm. 27.

27 Ibid..

28 Hadi Susanto, Pemegang Saham Nominee dalam Perseroan Terbatas, Tesis, Program Pascasarjana Magister Kenotariatan, Fakultas Hukum Universitas Sumatera Utara, 2004, hlm 88.

29 Ibid. 
atas kepemilikan saham tersebut. ${ }^{30}$

Dalam membuat struktur nominee tidak langsung, skema yang umumnya dilakukan di Indonesia adalah pinjam-meminjam dengan tahapan sebagai berikut: ${ }^{31}$

Nantinya perusahaan asing dan/atau warga negara asing meminjamkan sejumlah dana kepada nominee yang notabene Warga Negara dan/atau badan hukum Indonesia;

Perbuatan hukum pinjam-meminjam antara beneficiary dan nominee tersebut akan dilandasi dengan Akta Pengakuan Hutang atau Perjanjian Pinjaman sebagai perjanjian pokok;

Selain Akta Pengakuan Hutang yang menjadi perjanjian pokok, terdapat pula beberapa dokumen lainnya yang menjadi perjanjian yang bersifat accesoir atau perjanjian turunan dari perjanjian pokok tersebut. Perjanjian yang bersifat accesoir tersebut terdiri atas perjanjian yang diperuntukkan bagi kepentingan beneficiary dan perjanjian yang diperuntukkan bagi kepentingan nominee;

Keseluruhan dokumen tersbut nantinya akan menyamarkan kepemilikan saham beneficiary, sekaligus memberikan seluruh manfaat atas kepemilikan sahan nominee pada perseroan kepada beneficiary walaupun beneficiary tidak tercatat sebagai pemegang saham perseroan.

Di Indonesia sendiri, mengenai konsep nominee agreement kepemilikan saham dalam kegiatan Penanaman Modal pada dasarnya dilarang. Bahwa larangan tersebut diatur secara jelas yaitu di dalam Undang-Undang Nomor 25 Tahun 2007 tentang Penanaman Modal dan Undang-Undang Nomor 40 Tahun 2007 tentang Perseroan Terbatas. Bahwa di dalam Undang-Undang Nomor 25 Tahun 2007 tentang Penanaman Modal sendiri telah menyebutkan adanya sanksi yang melarang dalam hal terjadinya Perjanjian Pinjam Nama (nominee agreement) dalam keadaan tertentu. Bahwa dalam Pasal 33 ayat (1) dan ayat (2) UndangUndang Nomor 25 Tahun 2007 disebutkan:

(1) Penanam modal dalam negeridan penanam modal asing yang melakukan penanaman modal dalam bentuk perseroan terbatas dilarang membuat perjanjian dan/atau pernyataan yang menegaskan bahwa kepemilikan saham dalam perseroan terbatas untuk dan atas nama orang lain

(2) Dalam halpenanammodaldalamnegeridan penanam modal asing membuat perjanjian dan/atau pernyataan sebagaimana dimaksud pada ayat (1), perjanjian dan/ atau pernyataan itu dinyatakan batal demi hukum.

Dalam penjelasan Pasal 33 ayat (1) dinyatakan bahwa tujuan dari ketentuan tersebut adalah menghindari terjadinya perseroan yang secara normatif dimiliki seseorang, tetapi secara materi atau substansi pemilik perseroan tersebut adalah orang lain. Dari ketentuan tersebut dapat diketahui bahwa untuk kegiatan Penanaman Modal dalam bentuk perseroan terbatas, penanam modal yang menyatakan bahwa kepemilikan saham yang dia miliki adalah untuk dan atas nama orang lain yang namanya tidak tercantum sebagai pemegang saham di

30 Syahrijal Syakur, Op.Cit., hlm. 28.

31 Ibid., hlm. $28-29$. 
perseroan. Artinya pemegang saham tersebut hanya sebagai nominee dari seseorang yang sebenarnya memiliki modal dalam pendirian perseroan tersebut (beneficial owner), maka sesuai dengan ketentuan Pasal 33 ayat (2) UU Penanaman Modal maka Perjanjian tersebut adalah batal demi hukum.

Ketentuan Pasal 33 ayat (1) dan (2) Undang-Undang Nomor 25 Tahun 2007 tentang Penanaman Modal tersebut sejalan dengan ketentuan Pasal 48 ayat (1) Undang-Undang Nomor 40 Tahun 2007 tentang Perseroan Terbatas (UU PT) yang menyatakan bahwa Saham Perseroan dikeluarkan atas nama pemiliknya (saham atas nama (registered Stock). Adapun dalam penjelasan ketentuan Pasal 48 ayat (1) UU PT tersebut dinyatakan bahwa yang dimaksud dalam ketentuan ini adalah Perseroan hanya diperkenankan mengeluarkan saham atas nama pemiliknya dan Perseroan tidak boleh mengeluarkan saham atas tunjuk (bearer stock). Atas kepemlikan saham tersebut, pemegang saham diberi bukti pemilikan saham untuk saham yang dimilikinya. Artinya bahwa seorang pemegang saham dari suatu perseroan terbatas tidak mungkin menyatakan atau mengadakan perjanjian bahwa saham yang dia miliki adalah untuk dan atas nama orang lain atau pemegang saham tersebut hanya sebagai nominee. Begitupun sebaliknya, orang yang tidak tercantum atau tercatat sebagai pemegang saham pada perseroan terbatas tidak dimungkinkan untuk mengakui bahwa dengan adanya bukti perjanjian pinjam nama (nominee agreement) antara dia dengan pemegang saham, maka dia adalah pemilik sebenarnya dari saham pada perseroan terbatas.
Kemudian, ataskepemilikan sahamtersebut, seorang pemegang saham mempunyai hak yaitu untuk: menghadiri dan mengeluarkan suara dalam RUPS; menerima pembayaran dividen dan sisa kekayaan hasil likuidasi; dan menjalankan hak lainnya berdasarkan Undang-Undang ini. ${ }^{32}$ Artinya, jika suatu saham diatasnamakan oleh nominee, maka yang memperoleh hak-hak tersebut diatas kertas adalah nominee tersebut. Padahal, dibalik itu, nominee bertindak atas nama beneficiary nya. Sehingga apapun hak yang diperolehnya dimungkinkan untuk dikendalikan oleh beneficiary dari nominee tersebut.

Jika dilihat dalam Kitab Undang-Undang Hukum Perdata bahwa salah satu syarat suatu perjanjian sebagaimana dinyatakan dalam Pasal 1320 KUHPerdata adalah 'sebab yang halal'. Adapun dalam Pasal 1337 KUHPerdata dinyatakan bahwa yang menyebutkan "suatu sebab adalah terlarang, jika sebab itu, diantaranya, dilarang oleh undang-undang", maka terhadap praktik pinjam nama (nominee agreement), dalam bentuknomineeshareholders yang dilarang berdasarkan Pasal 33 ayat (1) UU Penanaman Modal dan Pasal 48 Ayat (1) UU Perseroan Terbatas, menjadikan perjanjiannya batal demi hukum. Hal ini mengakibatkan nominee agreement dalam penanaman modal tidak diakui di Indonesia sehingga tidak boleh dilaksanakan di hadapan hukum.

\section{Reformulasi Pengaturan Nominee Agreement dalam Kegiatan Penanaman Modal Asing Menggunakan Joint Venture Company}

Perusahaan Joint Venture merupakan perusahaan yang dibentuk berdasarkan perjanjian kerjasama antara entitas para 
pihak untuk membentuk sebuah perusahaan baru. ${ }^{33}$ Dalam hal ini, pihak pengusaha asing dengan lokal, pengusaha asing dengan asing, atau pengusaha lokal dengan lokal, sesuai dengan peraturan perundang-undangan di Indonesia membentuk suatu perusahaan baru yang disebut dengan perusahaan joint venture. Mereka yang membentuknya menjadi pemegang saham yang besarnya sesuai dengan kesepakatan bersama, dan tidak melanggar ketentuan peraturan perundang-undangan yang membatasi kepemilikan saham maksimum, baik bagi pengusaha asing ataupun pengusaha lokal (dalam negeri). ${ }^{34}$

Perjanjian Joint venture bagi investor asing sendiri bersumber dari ketentuan Pasal 12 ayat (4) UU Penenaman Modal yang menentukan adanya bidang usaha yang terbuka untuk modal asing, dan bidang usaha yang terbuka dengan persyaratan pembatasan kepemilikan saham. ${ }^{35}$ Ketentuan yang mengatur perihal tersebut, pada saat ini, dimuat dalam Peraturan Presiden Nomor 10 Tahun 2021 tentang Bidang Usaha Penanaman Modal. Berdasarkan Perpres tersebut, setidaknya terdapat bidang usaha: (a) Bidang usaha tertutup; dan Bidang Usaha Terbuka (terdiri atas: bidang usaha prioritas; bidang usaha yang diaiokasikan atau kemitraan dengan Koperasi dan UMKM, bidang usaha dengan persyaratan tertentu, dan bidang usaha terbuka lainnya). Bidang Usaha tertutup, merupakan bidang usaha yang tidak dapat diusahakan dengan kegiatan investasi. Adapun Bidang Usaha terbuka dapat diusahakan dengan kegiatan investasi. Tetapi khusus bagi investor asing, terdapat bidang usaha terbuka yang tidak dapat diusahakan melalui investasi asing. Misalnya, bidang usaha yang dialokasikan khusus untuk Koperasi dan UMKM dan bagian dari bidang usaha persyaratan tertentu, yang menentukan kepemilikan saham harus $100 \%$ dalam negeri.

Bagi investor asing, salah satu hal yang fundamental dalam melakukan kegiatan investasi asing melalui pendirian perusahaan joint venture adalah perihal kepemilikan saham. Adapun untuk pendirian perusahaan joint venture oleh entitas asing sendiri, berdasarkan Pasal 5 ayat (2) UU Penanaman Modal, maka perusahaan joint venture tersebut wajib berbentuk Perseroan Terbatas. Adapun pendirian Perseroan Terbatas, mensyaratkan pendiriannya harus didirikan oleh 2 (dua) orang atau lebih. Persyaratan pendirian perseroan terbatas dengan harus terdapat 2 (dua) orang atau lebih ini juga memicu kemungkinan timbulnya nominee shareholder, yang pada umumnya pemodal asing ingin menguasai perseroan terbatas secara tidak terbatas. ${ }^{36}$

Berdasarkan Analisa penulis, setidaknya ada 3 (tiga) motif pendirian perusahaan joint venture oleh entitas asing dengan menggunakan nominee shareholders (yang didahului oleh nominee agreement antara beneficiary dengan nominee), yang dapat didudukkan sebagai sebuah perbuatan yang melanggar hukum yaitu:

a. Dalam bidang usaha terbuka lainnya (yang memungkinkan investor asing memiliki saham 100\%), terdapat motif dari beneficiary yang hendak memperoleh

33 Ana Rokhmatuussa'diyah dan Suratman, Op.Cit., hlm. 118.

34 Erman Rajagukguk dan Rosa Agustina, Op.Cit., hlm. 105.

35 Ibid.

36 Lucky Suryo Wicaksono, Op.Cit., hlm. 44. 
keuntungan dengan maksimal. Akan tetapi, dengan adanya persyaratan pendirian perusahaan joint venture (berbentuk Perseroan terbatas), harus didirikan oleh 2 (dua) orang atau lebih yang dituangkan dalam akta pendirian perusahaan. Sehingga ia menggunakan nominee entitas asing (orang perorangan atau badan usaha) ataupun entitas dalam negeri untuk menjadi pihak kedua dalam pembentukan perusahaan joint venture tersebut;

b. Untuk bidang usaha prioritas, bidang usaha kemitraan dengan koperasi dan UMKM, dan bidang usaha dengan persyaratan tertentu (yang memungkinkan investasi dari investor asing, tetapi dengan batasan kepemilikan saham), terdapat motif dari beneficiary yang hendak memperoleh keuntungan dengan maksimal. Akan tetapi, dengan adanya persyaratan batasan kepemilikan saham oleh investor asing yang hendak dikelabui oleh investor asing tersebut, maka ia menggunakan nominee entitas dalam negeri (orang perorangan atau badan usaha) untuk menjadi 'pihak indonesia' dalam pembentukan perusahaan joint venture tersebut; dan

c. Dalam hal beneficiary (untuk orang perorangan) atau senior officer dari beneficiary (untuk badan usaha) merupakan pelaku tindak pidana, yang uang hasil kejahatannya tersebut hendak 'dicuci' (melakukan tindak pidana pencucian uang) melalui kegiatan investasi, dalam hal ini menyertakan modal pada pendirian perusahaan joint venture.

Sebagaimana dijelaskan pada subbahasan sebelumnya, bahwa apabila entitas (orang perorangan atau badan usaha) asing tersebut mendirikan sebuah perusahaan dengan menggunakan nominee di Indonesia, maka perjanjian pendirian perusahaan tersebut menjadi batal demi hukum. Dalam konteks ini, apabila suatu perusahaan joint venture melalui investasi asing dalam pendiriannya terdapat nominee, maka joint venture agreement tersebut menjadi batal demi hukum, sehingga perusahaan joint venture tersebut dianggap tidak pernah ada.

Selanjutnya, setelah penulis menelisik kedudukan beneficiary dalam suatu transaksi, setidak-tidaknya telah terdapat ketentuan yang mengatur tentang hal tersebut, sebagaimana dalam Peraturan Presiden Nomor 13 Tahun 2018 tentang Penerapan Prinsip Mengenali Pemilik Manfaat dari Korporasi dalam rangka Pencegahan dan Pemberantasan Tindak Pidana Pencucian Uang dan Tindak Pidana Pendanaan Terorisme (selanjutnya disebut sebagai 'Perpres BO'). Berdasarkan Pasal 3 Perpres BO dinyatakan bahwa "Setiap Korporasi wajib menetapkan Pemilik Manfaat dari Korporasi". Adapun salah satu variabel Pemilik Manfaat adalah 'pemilik sebenarnya dari dana atau modal korporasi'. ${ }^{37}$

Keberadaan Perpres BO yang mengatur eksistensi dari beneficiary bahkan ultimate beneficial owner dalam suatu Perusahaan (termasuk Perseroan Terbatas) terkait dengan pencegahan dan pemberantasan Tindak Pidana Pencucian Uang ini, semakin menguatkan

37 Lihat ketentuan Pasal 4 ayat (1) huruf g, Pasal 5 ayat (1) huruf e, Pasal 6 ayat (1) huruf f, Pasal 7 ayat (1) huruf e, Pasal 8 ayat (1) huruf e, Pasal 9 ayat (1) huruf e, dan Pasal 10 Ayat (10 huruf e Peraturan Presiden Nomor 13 Tahun 2018 tentang Penerapan Prinsip Mengenali Pemilik Manfaat Dari Korporasi Dalam Rangka Pencegahan Dan Pemberantasan Tindak Pidana Pencucian Uang Dan Tindak Pidana Pendanaan Terorisme 
hasil analisis penulis sebelumnya, bahwa salah satu motif pendirian perusahaan joint venture oleh asing dengan menggunakan nominee shareholders (yang didahului oleh nominee agreement antara beneficiary asing dengan nominee tersebut), dapat dimungkinkan dilakukan dalam rangka memuluskan upaya melakukan tindak pidana pencucian uang, terutama pada poin bahwa 'beneficiary (untuk orang perorangan) atau senior officer dari beneficiary (untuk badan usaha) merupakan pelaku tindak pidana, yang uang hasil kejahatannya tersebut hendak 'dicuci' (melakukan tindak pidana pencucian uang) melalui kegiatan investasi, dalam hal ini menyertakan modal pada pendirian perusahaan joint venture'.

Dengan merujuk pada ketentuan Perpres BO tersebut, timbul sebuah diskursus baru yang perlu untuk diuraikan. Yakni, bahwa di satu sisi, melalui UU Penanaman Modal dan UU Perseroan Terbatas, terdapat larangan keberadaan nominee shareholders (apapun bentuknya), yang secara mutatis mutandis terdapat beneficiary/ultimate beneficial owner-nya. Akan tetapi, di sisi lain, dengan merujuk pada Perpres BO, justru ada kewajiban bagi setiap korporasi (termasuk Perseroan Terbatas), untuk menetapkan Pemilik Manfaat (beneficial owner) dari suatu korporasi melalui identifikasi dan verifikasi beneficial owner dari perusahaan tersebut. ${ }^{38}$ Dari hal tersebut, dalam konteks penanaman modal asing, menurut analisa penulis, apabila eksistensi dari suatu nominee shareholders (yang dilakukan atas dasar nominee agreement antara beneficiary dengan nominee) dilarang dalam pembentukan perusahaan joint venture dalam investasi asing, maka akan timbul kecenderungan dari nominee untuk tidak mengungkap (disclose) informasi perihal siapa beneficiary/ultimate beneficial ownernya. Hal tersebut akan berkonsekuensi pada ketidakefektifan penerapan Perpres BO dalam konteks keberadaan perusahaan joint venture dalam investasi asing.

Dari uraian permasalahan tersebut, penulis menilai bahwa terhadap perusahaan joint venture dalam investasi asing, seyogjanya tidak dilakukan pelarangan secara total terhadap eksistensi nominee shareholders (yang dilakukan atas dasar nominee agreement antara beneficiary asing dengan nominee tersebut). Melainkan perlu dilakukan pembatasan-pembatasan terhadap konteks nominee shareholders yang dibolehkan dan tidak dibolehkan. Melalui hal tersebut, pihak perusahaan joint venture berbentuk Perseroan terbatas, wajib melakukan identifikasi dan verifikasi dengan benar perihal pihak-pihak dalam perusahaan tersebut yang hendak ditetapkan sebagai pemilik manfaatnya (termasuk beneficiary/ultimate beneficial owner-nya). Setelah ditetapkan siapa saja pemilik manfaatnya, pihak perusahaan joint venture tersebut wajib menyampaikan informasi tersebut kepada instansi yang berwenang, dalam hal ini Kementerian Hukum dan Hak Asasi Manusia. ${ }^{39}$

Jika opsi seperti di atas ini yang dilaksana-

38 Lihat Pasal 3 ayat (1) jo Pasal 15 ayat (1) Peraturan Presiden Nomor 13 Tahun 2018 tentang Penerapan Prinsip Mengenali Pemilik Manfaat Dari Korporasi Dalam Rangka Pencegahan Dan Pemberantasan Tindak Pidana Pencucian Uang Dan Tindak Pidana Pendanaan Terorisme

39 Lihat Pasal 18 Ayat (1) jo Pasal 13 Ayat (3) huruf a Peraturan Presiden Nomor 13 Tahun 2018 tentang Penerapan Prinsip Mengenali Pemilik Manfaat Dari Korporasi Dalam Rangka Pencegahan Dan Pemberantasan Tindak Pidana Pencucian Uang Dan Tindak Pidana Pendanaan Terorisme 
kan, akan dapat memperbesar kemungkinan pihak Perushaan joint venture tersebut mengidentifikasi secara benar pihak-pihak yang menjadi pemilik manfaatnya, termasuk pemilik manfaat sebenarnya (beneficiary/beneficial owner), atau dalam hal ini termasuk beneficiary dari nominee shareholders tersebut. Dalam konteks inilah batasan-batasan sebagaimana diuraikan sebelumnya diperlukan. Batasan tersebut diperlukan untuk mengidentifikasi apakah eksistensi dari nominee shareholders tersebut masih dibolehkan atau justru sudah tidak tepat lagi.

Adapun batasan-batasan yang diusung oleh penulis sebagai solusi yang ditawarkan untuk mengatasi permasalahan terkait nominee shareholders dalam suatu perusahaan joint venture dalam kegiatan investasi asing adalah bahwa di masa mendatang perusahaan joint venture dalam suatu kegiatan investasi asing, perlu memastikan bahwa:

a. Kepemilikan saham asing tidak boleh melampaui batas maksimum kepemilikan saham yang ditentukan dalam Perpres Nomor 10 Tahun 2021. Dalam konteks ini, pihak dalam negeri yang menjadi nominee dari orang/badan usaha asing, harus ditetapkan sebagai investor asing;

b. Pihak dalam negeri tidak dibolehkan menjadi nominee dari orang/badan usaha asing terhadap bidang usaha yang khusus dialokasikan untuk Koperasi dan UMKM, dan bidang usaha yang mensyaratkan kepemilikan saham dalam negeri sebanyak 100\%; dan

c. Pihak orang/badan usaha asing tidak boleh menunjuk nominee untuk melakukan investasi dengan menggunakan uang/harta kekayaan hasil tindak pidana. Untuk konteks ini, informasi tersebut bisa saja diperoleh melalui informasi atas pihak-pihak dari orang/badan usaha asing sebagai DPO dari Interpol, atau dari informasi-informasi officially lainnya dari negara calon investor tersebut, dll.

Apabila penjelasan-penjelasan yang diuraikan tersebut di atas ke depannya direformulasi dan dipositivisasi dalam UU Perseroan Terbatas, UU Penanaman Modal, dan undang-undang lain yang terkait, maka menurut sudut pandang penulis, hal tersebut merupakan hal yang lebih bijak dilakukan terhadap kegiatan investasi asing. Hal tersebut dikarenakan, di satu sisi, entitas asing (selaku beneficiary) tidak perlu khawatir lagi perihal nominee agreement yang hendak ia lakukan. Hal tersebut dikarenakan perjanjiannya dengan pihak nominee tidak serta-merta batal demi hukum lagi (selama tidak melanggar batasan-batasan yang ditentukan). Adapun di sisi lain, terdapat kemudahan bagi perusahaan joint venture untuk menentukan sebuah entitas sebagai nominee dari entitas asing atau bukan. Dan hal yang tidak kalah dari itu ialah terciptanya harmonisasi dan sinkronisasi antara ketentuan UU Penanaman Modal dan UU Perseroan Terbatas, dengan Perpres BO, sehingga terwujud sebuah kepastian hukum dalam rangka mengimplementasikan ketentuanketentuan tersebut.

Jika dipotret dari sudut pandang komparasi dengan negara lain sendiri, misalnya di Malaysia, perihal pengaturan Nominee Shareholders, telah diatur dan dituangkan dalam Laws of Malaysia Act 777, Companies Act 2016. Dalam Article 56 Companies Act of Malaysia tersebut, dinyatakan bahwa Perusahaan dapat meminta pemegang 
saham untuk menyampaikan dalam waktu yang ditentukan untuk: (a) Menginformasikan kepada perusahaan apakah pemegang saham bertindak sebagai pemilik manfaat atau sebagai trustee (nominee); (b) Jika pemegang saham bertindak sebagai trustee (nominee), maka dia sejauh mungkin menyediakan nama dan keterangan lain yang cukup terkait identitas dan kepentingan dari individu-individu untuk siapa dia memegang saham. ${ }^{40} \mathrm{Hal}$ tersebut, semakin menampakkan bahwa berdasarkan hukum positif Malaysia, mereka tidak melarang praktik nominee shareholders (yang dilakukan melalui nominee agreement antara beneficiary dengan nominee). Akan tetapi apabila seorang pemegang saham suatu perusahaan merupakan nominee shareholders, maka ia wajib menginformasikan siapa beneficiary atau ultimate beneficial owner dari pihak nominee shareholders tersebut.

\section{Penutup}

Nominee agreement merupakan sebuah perjanjian yang dilakukan antara beneficiary dengan nominee yang memberikan ruang kepada nominee untuk bertindak untuk dan atas nama beneficiary serta sesuai dengan petunjuk dan arahan dari beneficiary. Dalam konteks kepemilikan saham dalam korporasi (perseroan terbatas), pihak yang secara legal formal tercatat sebagai pemegang saham adalah nominee, sedangkan pihak yang mengendalikannya disebut sebagai beneficiary. Di sektor penanaman modal di Indonesia status quo, terhadap praktik nominee arrangement kepemilikan saham merupakan perbuatan yang dilarang, berdasarkan Pasal 33 ayat (1) UU Penanaman Modal dan Pasal 48 ayat (1) UU Perseroan Terbatas. Oleh karena dilarang oleh undang-undang, maka berdasarkan Pasal 1320 jo Pasal 1337 KUHPerdata, maka terhadap segala nominee agreement kepemilikan saham dalam suatu kegiatan investasi di Indonesia, pada saat ini, ditetapkan sebagai perjanjian yang batal demi hukum.

Adapun bentuk reformulasi pengaturan nominee agreement kepemilikan saham pada kegiatan penanaman modal asing yang menggunakan perusahaan joint venture di Indonesia ialah dengan mengubah arah pengaturan dalam UU Perseroan Terbatas, UU Penanaman Modal, dan undang-undang terkait lainnya, yang semula melarang praktik nominee agreement kepemilikan saham, menjadi membatasi terkait praktik mana yang legal, dan praktik mana yang melanggar hukum. Adapun batasan yang diusulkan oleh penulis dalam reformulasi pengaturan tersebut adalah: (a) Kepemilikan saham asing tidak boleh melampaui batas maksimum kepemilikan saham yang ditentukan dalam Perpres Nomor 10 Tahun 2021. Dalam konteks ini, pihak dalam negeri yang menjadi nominee dari orang/badan usaha asing, harus ditetapkan sebagai investor asing; (b) Pihak dalam negeri tidak dibolehkan menjadi nominee dari orang/badan usaha asing terhadap bidang usaha yang khusus dialokasikan untuk Koperasi dan UMKM, dan bidang usaha yang mensyaratkan kepemilikan saham dalam negeri sebanyak 100\%; dan (c) Pihak orang/badan usaha asing tidak boleh menunjuk nominee untuk melakukan investasi dengan menggunakan uang/harta kekayaan hasil tindak pidana. Untuk konteks ini, informasi tersebut bisa saja diperoleh melalui informasi atas pihak-pihak dari orang/badan usaha asing

40 Artticle 56 Paragraph 1 Laws of Malaysia Act 777, Companies Act 2016. 
sebagai DPO dari Interpol, atau dari informasiinformasi officially lainnya dari negara calon investor tersebut, dll.

Oleh sebab itu, dalam rangka mewujudkan harmonisasi norma agar dapat efektif dalam penyelenggaraannya, Penulis merekomendasikanagarperludilakukan peninjauanterhadap peraturan perundang-undangan di bidang investasi, perseroan terbatas, dan peraturan terkait lainnya, dan mengkoherensikannya satu sama lain. Koherensi dari aturan tersebut harus merupakan sebuah wujud konkret manifestasi dari Pasal 33 UUD Negara RI Tahun 1945. Peninjauan terhadap peraturan perundanganundangan yang dimaksud di atas ialah dengan mentransformasi bentuk pengaturan nominee shareholders, termasuk apabila beneficiarynya adalah asing (diperjanjikan melalui nominee agreement) dalam konteks perusahaan joint venture pada Penanaman Modal Asing, yang pada status quo berbentuk pelarangan secara total terhadap kemungkinan tersebut, menjadi sebuah pembatasan terhadap praktik-praktik nominee shareholders berdasarkan peraturan perundang-undangan terkait. Pembatasan tersebut di antaranya, misalnya, apabila nominee shareholders yang beneficiarynya adalah entitas asing harus dianggap sebagai 'pihak asing', sehingga dalam konteks pembentukan perusahaan joint venture tetap harus memperhatikan batasan kepemilikan saham oleh asing. Selain itu, juga tidak dibolehkan apabila beneficiary asing menunjuk nominee shareholders di Indonesia, jika dilakukan dalam rangka melakukan pencucian uang dengan skema investasi. 


\section{DAFTAR PUSTAKA}

\section{A. Buku}

Bagus Rachmadi Supancana, Ida, Kerangka Hukum dan Kebijakan Investasi Langsung di Indonesia, (Jakarta: Ghalia Indonesia, 2006).

Fuady, Munir, Hukum Bisnis Dalam Teori dan Praktek, Buku 3, (Bandung: Penerbit PT. Citra Aditya Bakti, 2002).

Hingorani, R.C., Modern International Law: Second Edition, (New Delhi: Oxford \& IBH Publishing Co, 1982).

J. Nagy, Pancras, Country Risk: How to Asses, Quantify, and Monitor, (London: Euronomy Publications, 1979).

Kirupan, David, Aspek Hukum Penanaman Modal Asing Di Indonesia, (Jakarta: Penerbit Kencana

Prenada Media Group, 2013).

Rajagukguk, Erman, dan Rosa Agustina, Hukum Investasi dan Pasar Modal, (Jakarta: Pascasarjana FHUI, 2010).

Rokhmatussa'dyah, Ana, dan Suratman, Hukum Investasi dan pasar Modal, (Jakarta: Sinar Grafika, 2009).

Sedarmayanti \& Syarifudin Hidayat. Metodologi Penelitian, (Bandung: Mandar Maju, 2002).

Sonny Keraf, A., dan Mikhael Dua, Ilmu Pengetahuan, Sebuah Tinjauan Filosofis, (Yogyakarta: Kanisius, 2001).

Syakur, Syahrijal Urgensi Pengaturan Nominee Agreement Dalam Rangka Pencegahan Tindak Pidana Pencucian Uang, (Jakarta: PPATK, 2020).

\section{B. Makalah/Artikel/Prosiding/Hasil Penelitian}

Indriyani, lin "Perkembangan Hukum: Perseroan Terbatas Dan Praktik Penggunaan Nominee

Oleh Investor Asing", (makalah disampaikan pada Prosiding Seminar Ilmiah Nasional Fakultas Hukum Universitas Pamulang, Pamulang, Indonesia, Juli 2017).

Suryo Wicaksono, Lucky, "Kepastian Hukum Nominee Agreement Kepemilikan Saham Perseroan terbatas", Jurnal Hukum lus Qua lustum, Vol.23 No.1, (Januari 2016).

Susanto, Hadi, "Pemegang Saham Nominee dalam Perseroan Terbatas", Tesis, Program Pascasarjana Magister Kenotariatan, Fakultas Hukum Universitas Sumatera Utara, 2004.

\section{Putusan Pengadilan}

Putusan Mahkamah Konstitusi Nomor 36/PUU-X/2012 tentang Pengujian Undang-Undang Nomor 22 Tahun 2001 tentang Minyak dan Gas Bumi terhadap Undang-Undang Dasar Negara Republik Indonesia Tahun 1945, kaitannya dengan pemaknaan 'Hak Menguasai Negara' pada Pasal 33 ayat (2) dan ayat (3) Undang-Undang Dasar Negara Republik Indonesia Tahun 1945.

\section{Peraturan Perundang-Undangan}

Undang-Undang Dasar Negara Republik Indonesia Tahun 1945.

Undang-Undang Nomor 25 Tahun 2007 tentang Penanaman Modal 
Undang-Undang Nomor 40 Tahun 2007 tentang Perseroan Terbatas

Undang-Undang Nomor 11 Tahun 2020 tentang Cipta Kerja

Peraturan Presiden Nomor 13 Tahun 2018 tentang Penerapan Prinsip Mengenali Pemilik Manfaat

Dari Korporasi Dalam Rangka Pencegahan Dan Pemberantasan Tindak Pidana Pencucian Uang Dan Tindak Pidana Pendanaan Terorisme

Peraturan Presiden Nomor 10 Tahun 2021 tentang Bidang Usaha Penanaman Modal Laws of Malaysia Act 777, Companies Act 2016. 


\section{BIODATA PENULIS}

Muh. Afdal Yanuar, S.H. menyelesaikan program sarjananya di Program Studi S1 Ilmu Hukum, Fakultas Hukum Universitas Hasanuddin dengan Program Kekhususan Hukum Pidana. Selama tercatat sebagai Mahasiswa di Fakultas Hukum UNHAS, tercatat berhasil beberapa kali mengukir prestasi di antaranya: Juara I Lomba Sidang Semu MPR tingkat Nasional dengan agenda sidang "Perubahan UUD Negara Republik Indonesia tahun 1945" pada Padjadjaran Law Fair tahun 2014, Juara I Lomba Peradilan Semu Mahkamah Konstitusi tingk. Nasional pada Gebyar Konstitusi tahun 2015, Juara I Lomba Debat Reformasi Birokrasi pada Pekan Kreativitas Mahasiswa Administrasi Indonesia (PKMAI) tahun 2015 tingk. Nasional, dan Juara I sekaligus Best Speaker pada Debat Konstitusi Tingkat Nasional Diponegoro Law Fair IV Tahun 2016, bahkan ia keluar sebagai Wisudawan Terbaik Fakultas Hukum UNHAS dan Wisudawan Terbaik UNHAS pada periode Wisuda Maret 2017. Selepas menyelesaikan studinya ia bekerja di Pusat Pelaporan dan Analisis Transaksi Keuangan. Disana, ia aktif melakukan penelitian dan menjadi pengajar pada beberapa instansi terkait dengan Rezim Anti Pencucian Uang dan Pemberantasan Pendanaan Terorisme (APU-PPT). Diantaranya, pernah menjadi Pengajar pada Pendidikan dan Pelatihan Fungsional Sertifikasi Calon Hakim Tindak Pidana Korupsi di Balai Diklat Hukum dan Peradilan Mahkamah Agung Tahun 2019, 2020, dan 2021, dan Pengajar/Narasumber perihal "Penanganan Perkara TPPU” pada Pendidikan Calon Penyidik Tindak Pidana Korupsi di Gedung Pusat Edukasi Antikorupsi, Tahun 2019, serta Pengajar pada beberapa DIKLAT di PUSDIKLAT APU-PPT.

Pada saat ini ia sedang melanjutkan studinya pada Jurusan Hukum Ekonomi pada Program Studi Magister (S2) Ilmu Hukum Fakultas Hukum Universitas Indonesia. Setidaknya hingga saat ini terdapat beberapa tulisannya yang telah terpublikasi, yaitu: Diskursus Antara Kedudukan TPPU sebagai Independent Crime dengan sebagai Follow Up Crime Pasca Putusan MK No 90/PUU-XIII/2015, pada Jurnal Konstitusi Vol. 16, No. 4, Desmber 2019; Obat Mujarab Atas Harapan Palsu yang Dialami Korban First Travel, pada Majalah IFII (Indonesian Financial Intelligence Institute) Vol. 4, Juni Tahun 2020; dan Pembalikan Beban Pembuktian Dalam Proses Pembuktian Perkara Tindak Pidana Pencucian Uang, Jakarta: PPATK, 2020. 